\title{
Editorial da Edição Especial
}

Esta é a primeira edição especial da Revista de Administração Contemporânea, desde a sua criação, em 1997. Assim, é com enorme satisfação que escrevo o presente editorial. É sempre interessante fazer a abertura de uma iniciativa que promete se repetir a cada ano, com evidentes ganhos para a comunidade científica e para o próprio desenvolvimento da revista como veículo fundamental de divulgação da produção acadêmica relevante do campo da Administração no país.

Antes de tudo é preciso registrar que constitui notável privilégio para a área de Estudos Organizacionais inaugurar a série de edições especiais da RAC. Esse privilégio não é gratuito. Decorre do fato de ser a área pioneira, no âmbito da ANPAD, em se estabelecer como grupo, ainda que de maneira informal; também pioneira, sob os auspícios da associação, a iniciar a organização de eventos temáticos com a realização do $1^{\circ}$ Encontro de Estudos Organizacionais - ENEO 2000, em Curitiba, Paraná.

Nada mais natural, portanto, o foco em Estudos Organizacionais da presente edição especial. Os 11 artigos que dela fazem parte constituem subgrupo de um total de 21 trabalhos, escolhidos entre os 53 apresentados durante o ENEO 2000. Está previsto que os 10 outros textos deverão integrar edição especial da revista portuguesa Comportamento Organizacional e Gestão, sob a editoria conjunta da Professora Suzana Braga Rodrigues e do Professor Miguel Pina e Cunha.

Os critérios adotados para a escolha dos artigos que compõem a presente edição foram, basicamente, o tema abordado e o número de pontos obtidos no processo de avaliação anônima (blind review) de todos os trabalhos submetidos para o evento. Ao se dar destaque, em especial, à questão do tema, ressalta-se que diversos textos não incluídos o seriam em outras circunstâncias. Cabe acrescentar, ainda, que vários trabalhos foram excluídos do processo de seleção por já terem sido escolhidos para integrar um livro a ser organizado pelo autor deste editorial - tal é o caso, por exemplo, dos artigos que se enquadram no campo da teoria institucional.

O tema praxis organizacional - teoria, pesquisa e ensino foi especialmente privilegiado, em face dos questionamentos freqüentes que têm sido feitos, nos últimos anos, sobre o ensino e a pesquisa, sobre teoria e construção do conhecimento, sobre a fragmentação e a identidade da área de Estudos Organizacionais no país. Na seqüência procura-se descrever, de forma breve, os 11 artigos que compõem esta edição e que trafegam sobre diversos temas desde aprendizagem e gestão do conhecimento em organizações até identidade organizacional.

No primeiro artigo, Peter Spink procura demonstrar o potencial do conceito de lugar, como espaço de produção de sentido e de ação, para a estudo do fenômeno organizacional como um todo. A seguir, Clóvis L. Machado-da-Silva e Eros E. da Silva Nogueira analisam os fatores cognitivos e simbólicos que ocasionaram a manutenção da identidade organizacional da Alfândega brasileira e a mudança de identidade da Telecomunicações do Paraná S/A. Fernando Prestes Motta, Rafael Alcadipani e Ricardo Bresler argumentam, em seu texto, que a valorização do estrangeiro contém forte papel 
de segregação social, que vem sendo negligenciado nas análises do estrangeirismo no mundo organizacional. Suzana Braga Rodrigues e Alexandre de Pádua Carrieri apresentam a evolução dos estudos organizacionais no Brasil, com base nos temas mais freqüentes e na importância relativa da literatura estrangeira nos artigos publicados nos periódicos da área de Administração, sugerindo pontos para reflexão. Sylvia Constant Vergara e Mario Couto Soares Pinto verificam a nacionalidade dos autores referenciados na literatura brasileira sobre organizações, comparando dois períodos 1989-1993 e 1994-1998, e concluem que as referências norte-americanas têm sido as mais utilizadas. Tânia Fischer, apoiando-se em pesquisa realizada com professores de pósgraduação, reflete sobre o que se ensina no Brasil na área de organizações e gestão, e de que forma o conhecimento é selecionado e reorganizado como matéria de ensino nos diversos níveis em que é ministrado. Carlos Cabral-Cardoso procura compreender, com base em estudo sobre a integração de doutores em organizações empresariais, em Portugal, a atração e a receptividade a uma carreira nas empresas, a partir das atitudes em relação à ciência enquanto prática de trabalho e enquanto profissão. O estudo de Sergio Bulgacov e Fabiane Cortez Verdu visa a identificar as relações em rede que existem entre os pesquisadores que participaram do Encontro Anual da Associação Nacional dos Programas de Pós-Graduação em Administração de 1999, com o objetivo de sugerir caminhos para a formação de grupos. Maria Tereza Fleury e Afonso Fleury recuperam o debate teórico a respeito da noção de competência, explicitando o conceito em seus vários níveis de compreensão e relacionando-o à estratégia e aos processos de aprendizagem organizacional. Miguel Pina e Cunha, João Vieira da Cunha e Sônia Dahab abordam, em seu texto, cinco princípios de uma visão dialética de qualidade: menos inspeção para promover a qualidade dos produtos; controle para promover a autonomia; liderança autoritária para promover a participação; desconfiança para promover a confiança; e rotinização/planejamento rígido para promover a criatividade. Por fim, Ursula Wetzel descreve a transformação do contrato psicológico no caso de duas empresas brasileiras, do setor de serviços, privatizadas no biênio 1997-1998, destacando que a sua renegociação requer o entendimento não apenas dos aspectos relativos às promessas percebidas pelos funcionários, mas também de outros aspectos externos ao contrato.

No seu conjunto, os artigos constituem amostra do nível de amadurecimento do campo de Estudos Organizacionais no Brasil. Os ensaios teóricos trazem contribuições analíticas relevantes. Os trabalhos teóricoempíricos tratam a metodologia de maneira cuidadosa, bem como procuram, de forma consistente, articular o quadro de referência conceitual com os dados empíricos. O nível de análise dominante nos textos que integram esta edição especial é o organizacional, o que significa a predominância de estudos que utilizam perspectivas macro relativamente àqueles que se detêm na verificação do relacionamento entre o indivíduo e a organização.

Para finalizar, espera-se que a composição desta primeira edição especial atenda às expectativas dos leitores e colaboradores da RAC, em especial daqueles especializados em Estudos Organizacionais.

Clóvis L. Machado-da-Silva Editor da Edição Especial 